My Jingi is back and the bush-lands are shining with glory; Aiye, let us be happy! To-day has my Jingi come home. Kola-nuts brought from the market are not for my Jingi, He says that the nuts on the stalls have a bosi-cake taint. ${ }^{2}$

Shoes that are brought from the market are not for my Jingi, He says that the shoes on the stalls have a bosi-cake taint. The flesh of the he-goat is not good enough for my Jingi. The goat, with its little short life, and its little short legs.

Way, there! Make way! Let her enter, the mother who bore him. O Mother of Children, your womb has enthroned you a queen! O Mother, your womb has become a Male Snake of good omen, ${ }^{3}$ Lie down and sleep, while your head is attired, and encircled with beads. ${ }^{4}$

The following verses contain allusions to the particular circumstances in which the present version was sung, and are naturally varied to suit the occasion. Each of the relatives is mentioned, and praised or disparaged according to his or her contribution to the feast:

O Father of Children, would one bull have emptied your steadings?

$O$ Father of Children, to-day you are shamed unto death.

O sister of his father, to whom is the share of the dowry.

O inna, his aunt, to-day you are shamed unto death;

Busied with cooking and serving,

Busied with: 'Bring me my mat,'

And 'Yea Lord, I hear and obey.' 5

\title{
The Moral Aspect of Native Education.
}

AN interesting discussion recently took place in the Committee on Applied Anthropology of the Royal Anthropological Institute, when Major Hanns Vischer, Joint Secretary of the Colonial Office Advisory Committee on

I Jingi is a nickname given to a boy who has undergone the circumcision rites.

2 He must have his kola-nuts bought straight from the merchant, and not from the market where they might smell of bosi (a preparation of fish, \&c.).

3 If the ngorori snake bite you, and you die, you are counted a martyr; if you do not die, you will live to be rich. So also in childbirth; whether you live or die, you are lucky.

4 Bafdi is the name of the special style of hair-dressing which a mother wears when she has borne a child, for four months in the case of a son, and three months in the case of a daughter. She does not really do this again at the nastordu; the words are sung to her by the women in remembrance of the time when her child was born.

5 One of the aunts was so engrossed in her domestic affairs that she forgot to prepare a present for her nephew. 
Education in the Colonies, spoke on the difficulty of inculcating a moral code as part of a system of education divorced from tribal traditions. $\mathrm{He}$ pointed out that education in its higher branches is being more and more taken over by Governments, who, although they allow religious teaching to be given, do not make it part of the organized programme as is done by the Christian missions. The products of that system as he saw them in London did not appear to have assimilated a moral code which was felt as effective in the absence of the sanctions of the native environment; but the former pupils of Achimota College made a striking exception to this generalization, of which Major Vischer invited an explanation.

In discussion it was pointed out that Achimota is in many ways unique. Both teachers and students are very carefully selected, the latter coming from families in a position of economic security, a consideration which has a direct bearing on the question of adherence to socially prescribed standards. At Achimota native tradition is presumed to be worthy of respect, in contrast to the somewhat unsympathetic attitude towards it of some other educational institutions. Finally, great pains are taken to find employment for Achimota students, and they remain in touch with the college with its own tradition of membership of an élite.

Achimota, however, is one of the limited number of institutions training men primarily for a life in a more or less Europeanized environment. Other considerations are important in the case of schools such as the Yaba Higher College in Nigeria where the pupils are for the most part destined to return to the rural areas, either as teachers or through inability to find employment. Here the question arises of the moral principles which could be taught in a school which draws pupils from several different tribes whose traditional standards are not uniform, and also of the effect of the diffusion through the village areas of the principles learnt at school. The assumption that the Christian code of ethics provides the answer is open to the criticism that this code is at variance with the reality of the social system which European administrations have introduced into Africa, and is apt to be rejected by Africans when they become aware of that fact. It was suggested that a task which awaits the anthropologist is the construction of a code based on sociological realities, but that he has not at present the data which would equip him for such work. (Communicated by DR. L. P. Marr.)

\section{Some Aspects of Native Education and Culture Contact.}

To the student of educational problems in Africa, Mr. W. C. Groves's Native Education and Culture Contact in Nen Guinea ${ }^{\mathbf{I}}$ will be of value in many ways. It contains a good statement of the scientific approach to administrative problems in general and to those of native education in particular. The author draws very largely upon African material in building up his argu-

I Melbourne University Press. Pp. 179. Price 6s. 